This is a final draft pre-print that was published in: Joshua Pearce, "Photovoltaics - A Path to Sustainable Futures", Futures 34(7), 663-674, 2002. Available: doi:10.1016/S0016-3287(02)00008-3

\title{
Photovoltaics - a Path to Sustainable Futures
}

\author{
Joshua M. Pearce* \\ Science, Technology, and Society Program \\ The Pennsylvania State University
}

\begin{abstract}
As both population and energy use per capita increase, modern society is approaching physical limits to its continued fossil fuel consumption. The immediate limits are set by the planet's ability to adapt to a changing atmospheric chemical composition, not the availability of resources. In order for a future society to be sustainable while operating at or above our current standard of living a shift away from carbon based energy sources must occur. An overview of the current state of active solar (photovoltaic) energy technology is provided here to outline a partial solution for the environmental problems caused by accelerating global energy expenditure. The technical, social, and economic benefits and limitations of photovoltaic technologies to provide electricity in both off-grid and on-grid applications is critically analyzed in the context of this shift in energy sources. It is shown that photovoltaic electrical production is a technologically feasible, economically viable, environmentally benign, sustainable, and socially equitable solution to society's future energy requirements.
\end{abstract}

Keywords: energy, power, solar, photovoltaic

"Joshua Pearce

Science, Technology, and Society Program

The Pennsylvania State University

201D Old Botany Building

University Park, PA 16802

Email: jmp228@psu.edu

Fax: (814) 863-5341

\section{Introduction}

Although global fossil fuel resources have not yet been exhausted, the negative social, health, and environmental impacts of our current unsustainable patterns of energy use are apparent $[1,2,3,4,5]$. In the future, large-scale alternative methods of producing the vast quantities of energy needed to sustain and enhance our standard of living are necessary [6,7,8]. As Peter Harper proposed, the problem of contemporary society can be stated succinctly: "We need to get (probably) 11 billion people through the transition complex to 'Sustainia', the sustainable state, before irreversible damage is done" [9]. If current trends continue, future society will require increased electrical energy. This energy must be produced using sustainable technologies in order for society to continue to prosper indefinitely. Fortunately, advances in science and technology have provided us with several alternative means of producing energy on a sustainable level, such as wind, geothermal, biomass, and solar [10]. Of these means, solar (photovoltaic technology) provides the most widely adaptable applications and converts sunlight directly into electrical energy with the highest efficiencies $[11,12]$. This paper will demonstrate 
This is a final draft pre-print that was published in: Joshua Pearce, "Photovoltaics - A Path to Sustainable Futures", Futures 34(7), 663-674, 2002. Available: doi:10.1016/S0016-3287(02)00008-3

that photovoltaic (PV) electrical production is a technically feasible, economically viable, environmentally benign, sustainable, and socially equitable solution to modern society's energy requirements.

\section{Overview}

Since the beginning of the 1990's the public has slowly accepted that there is a link between global warming and carbon dioxide $\left(\mathrm{CO}_{2}\right)$ concentration despite an information war between climate scientists and the fossil fuel industry. The global mean surface temperatures have increased $0.6-1.2^{\circ} \mathrm{F}$ since the late 19 th century while the atmospheric $\mathrm{CO}_{2}$ concentration has increased by more than $30 \%$ to the highest level in 160,000 years $[1,7,13,14]$. In 1995 , the Intergovernmental Panel on Climate Change (IPCC) made up of over 2,500 scientists representing more than 80 countries undertook a review of the current state of climate change science (views presented in the report stem from the analysis of over 20,000 articles from the relevant literature) [15]. More recently the IPCC updated their prediction to state that globally average surface air temperatures is projected to warm by 1.4 to $5.8^{\circ} \mathrm{C}$ by 2100 (relative to 1990), and globally averaged seal level is projected to rise 0.09 to 0.88 meters over the same time [16]. It is now quite clear that certain gases, such as $\mathrm{CO}_{2}$, play a crucial role in determining the earth's climate. These 'greenhouse' gases increase the average global temperature by allowing the transmission of solar energy as visible light, which is then absorbed by the earth and re-radiated and trapped as heat. This heat is prevented from escaping into space by these same gases in the atmosphere following the same principle that governs greenhouses or the passenger compartment of a car left in the sun. Researchers have also documented that the increased concentration of such gases in the atmosphere resulted from human activities, predominantly the burning of fossil fuels [15]. It is therefore astute to reduce the burning of these fossil fuels as much as possible to limit the effects of global climate change via emissions of $\mathrm{CO}_{2}$.

Several international summits convened specifically to reduce the emissions of heattrapping gases because of the adverse consequences of human induced climate change. In December 1997, at the international Climate Summit in Kyoto, Japan, nations agreed to reduce greenhouse gas emissions by an average of five percent from 1990 levels between the year of 2008 and 2012. Under the accord, the United States will lower the emissions by 7\%, Japan by $6 \%$, and the European Union countries by 8\% [17]. Largely ignored, is that even if the Kyoto goals are met (which appears extremely unlikely), reductions in atmospheric $\mathrm{CO}_{2}$ would be an entire order of magnitude below those necessary to stabilize the global climate (atmospheric scientists generally agree that $60-70 \%$ reductions would be needed) [18]. Despite their limitations, these internationally backed environmental imperatives have become a driving force behind the development and utilization of PV solar energy, which does not contribute to greenhouse gas emissions during their use.

Individual countries have also made a large drive for PV development by sponsoring progressive energy subsidies for photovoltaics. In Japan, where approximately half of the world's 200MW production (as of 1999) of PV is used ${ }^{1}$, a recent subsidy for residential systems resulted in the cumulative number of systems climbing over 34,000 [19]. Because of the huge consumer interest, Japan decreased its subsidy from 50\% (1997) to 35\% (fiscal year 1999), yet

\footnotetext{
${ }^{1}$ The energy units used throughout will be in watts (W) and the power units in watt-hours (W-hrs) where $\mathrm{k}$ is $10^{3}, \mathrm{M}$ is $10^{6}$ watts, and $\mathrm{G}$ is $10^{9}$ respectively.
} 
This is a final draft pre-print that was published in: Joshua Pearce, "Photovoltaics - A Path to Sustainable Futures", Futures 34(7), 663-674, 2002. Available: doi:10.1016/S0016-3287(02)00008-3

between April 1999 and March 2000 over 17,000 systems were applied for [20]. The European Commission has increased its expenditures to 547 million Euro in order to reach their target goals of $0.075 \mathrm{GW}$ installed by 2003 and 3GW installed by 2010 [21]. The stand-out European PV program is the German 100,000 Roofs program - which is a ten year interest free loan. That, combined with their price-incentive program, buying PV in Germany is fully economical [20] now. The United States is also trying to create a solar energy option. In 2000, the Department of Energy spent \$17 million for cost-shared PV projects and that will increase to \$19 million in 2001 [22]. By far the most ambitious U.S. government program is the Million Solar Roofs Initiative, which will enable businesses and communities to install solar systems on one million rooftops across the United States by 2010 [23]. The million solar roofs project, on target in 1999 (nearly 0.3MW of mostly grid connect schools) and 2000, and looks to be on target for installed capacity in 2001 [22]. Individual states are also contributing to the promotion of solar power. California instituted a buy down program $(\$ 3.00 / \mathrm{Wp} \text { subsidy })^{2}$ that resulted in $200 \mathrm{PV}$ systems in the $2-4 \mathrm{~kW}$ range being installed [20]. The U.S. government is also continuing to support research into PV, investing $\sim \$ 76.7$ million in 2001 [22].

On a national scale, the rationale for promoting the adoption of PV technology is that PV is critical to energy security, strategic technology, and long-term economic growth [21]. As a distributed generation source, this technology acts as a network (much like the internet), and unlike the conventional grid. It is therefore much less susceptible to large-scale power outages caused by natural (e.g. floods, storms, etc.) or manmade disasters (e.g. terrorism, warfare, etc.). Solar energy also mitigates dependence on foreign energy supplies and thus reduces the need for military action. Finally, it provides benefits for domestic the economies due to the relative laborintensive [24] nature of the PV industry and the elimination of energy commodity imports [25].

\section{Feasibility: Resource and Technical Limitations}

Unlike the current methods that produce the majority of electrical energy, PV is a renewable resource. Thus, PV will continue to produce power indefinitely (as long as the sun shines). Contrary to popular perceptions, with current conversion efficiencies there is more than enough sunlight to easily provide global energy needs both now and in the future. There is a commonly held misconception that sustainable energy via solar cells comes at the price of large surface areas in selected regions [26]. This is simply untrue. The total solar radiation falling on the earth is $1.2 \times 10^{14} \mathrm{~kW}$, which is roughly 10,000 times current world consumption [27]. It would not even be necessary to cover an appreciable area of the planet with PV to provide for current world power from current solar cells (which are generally $~ 10 \%$ efficient). The fossil fuel production of the entire planet could be replaced by hydrogen generated by photovoltaic arrays on an estimated 53 million hectares of arid land (less than $2 \%$ of the area of the world's deserts) [25]. In the U.S. the estimations are comparatively bright. The U.S. average solar input is 1,825 $\mathrm{kW}-\mathrm{hr} / \mathrm{m}^{2}$ per year [28]. Even with cells of only $5 \%$ efficiency ${ }^{3}$, PV could easily provide all of the U.S.'s electrical needs without encroaching on arable land or sequestering panels in the desert. Ideally, solar panels would be located near the consumer in order to eliminate

\footnotetext{
${ }^{2}$ The Wp unit represents a measure of the peak power in watts that a solar cell outputs under 1 sun illumination.

${ }^{3} \mathrm{PV}$ panels are now only fabricated with such low efficiencies when used for ornamental reasons (e.g. as a replacement for architectural glazing).
} 
This is a final draft pre-print that was published in: Joshua Pearce, "Photovoltaics - A Path to Sustainable Futures", Futures 34(7), 663-674, 2002. Available: doi:10.1016/S0016-3287(02)00008-3

transmission losses ${ }^{4}$ and limiting support structure costs. This is accomplished by placing solar panels on, or building them into: roofs, building facades, carports, highway sound barriers, etc. Any surface that is exposed to sunlight is a potential location for PV. Thus, an inconsequential area covered by standard solar cells could easily provide the electrical needs of modern society.

Photovoltaic energy production is not a complete solution to all of society's energy requirements, however. PV is hampered my several disadvantages due to its physical nature, namely solar cells only produce energy when illuminated. Thus, to ensure power availability at night solar energy would be produced in excess during the day and stored for use at night. Currently, batteries are most commonly used to store this energy. The major disadvantage of batteries is the added initial capital investment and the greatly augmented upkeep. Solar cells themselves are solid-state devices with no moving parts and thus have negligible upkeep once installed. In a typical home PV/battery system the most economical batteries need to be replaced after $\sim 5$ years - thus, also greatly increasing the cost of production for an installed system. Homes with access to the grid could eliminate the need for batteries by inverting their solar energy from DC to AC and supplying excess energy onto the grid. In this way the grid effectively works as a storage medium. It is also possible to couple solar power generating facilities with other conventional sources. For instance, the World Bank recently funded a project that increased the power production of a hydroelectric power plant by adding arrays of solar modules [29]. The solar modules produce power during the day with the hydro plant holding the water in reserve until the night, when it takes over power production. Using similar methods society could double the generation capacity of its current energy plants without increasing environmental damage due to damming additional rivers or emitting more $\mathrm{CO}_{2}$. As an added advantage to using solar for symbiotic energy production, when electrical demand is highest for many electrical suppliers (during the summer for air conditioning) PV power output is at or near its peak. Thus solar power facilities can be used to mitigate peak demand and thus hold down costs for current energy suppliers.

Although select regions of the earth's surface that are exposed to higher solar fluxes, are optimal locations for PV arrays this does not preclude the use of solar cells in non-optimal locations. There are lightly inhabited regions where solar energy production is not viable (such as Northern Alaska) due to long periods of deficient sunlight. However, PV is viable in many locations normally perceived as inhospitable to solar technology [30]. The average yearly solar flux for Maine is $1 / 2$ that of New Mexico. Thus, although a solar array located in New Mexico can produce twice as much energy as an identical array in Maine, solar cells can still be used to generate the necessary energy in the areas available.

\section{Economic Viability}

Although solar energy production only commands a small part of the energy pie its slice is rapidly increasing as the price per peak Watt continues to decrease. The world market for photovoltaics exceeded 200MW in 1999, and 260MW were delivered in 2000 [20]. Shipments increased by 52\% in the U.S. [31] and 63\% in Japan [20]. The increases in shipments in 1999 were partially due to the Y2K hysteria but also the large export market (75\% of U.S. whole [31]), which was driven by an increase in subsidies in Japan and Europe (most notably Germany). This remarkable increase in solar energy use was a huge boost to PV manufacturers. To guide it

\footnotetext{
${ }^{4}$ Transmission losses can be higher than $50 \%$ on antiquated grid lines.
} 
This is a final draft pre-print that was published in: Joshua Pearce, "Photovoltaics - A Path to Sustainable Futures", Futures 34(7), 663-674, 2002. Available: doi:10.1016/S0016-3287(02)00008-3

through these increases the U.S. photovoltaics industry designed a roadmap based on a similar roadmap used for the semiconductor microelectronics industry. The conservative annual growth rate of $25 \%$ estimated by the PV industry was relatively minuscule compared to the reality of the market. The roadmap predicted that by 2020 the U.S. PV industry will be shipping $6 \mathrm{GWp} / \mathrm{yr}$ (3.2 GWp/yr for domestic use) and thus have cumulatively installed $\sim 87 \mathrm{GWp}$ [32]. These rather large numbers must be kept in perspective - the U.S. peak electrical generation capacity in 1999 was $\sim 776 \mathrm{GWp}[33]$ and will likely grow by 2020 . The transition to PV power production has only just begun.

A frequent critique of the PV industry is that it can not survive on a level-economic playing field - that it needs subsidies in order to survive. This critique is baseless when considered in the context of the massive public subsidies for the energy industry as a whole. Fossil fuels and nuclear energy receive $90 \%$ of U.S. government money, which comes to $\$ 43.3$ billion (with PV receiving only 3\%) [34]. This figure does not include the hidden costs that society subsidizes for the energy industry which include: health impacts (at least $\$ 40$ billion annually), military (U.S. military spends between $\$ 14.6$ and $\$ 54$ billion/yr just defending the oil supplies in the Persian Gulf), employment, crop loss, corrosion, and global warming [34]. In the ideal world on a level playing field, PV would be by far an economically superior energy source.

In the real world, if PV technology is going to succeed, it must become economically competitive in the current subsidized market. PV will accomplish this with economy of scale. As the production volume of solar cells increases the price per module falls rapidly, just as the price of computers plummeted from million of dollars to only several hundred when in mass production. This trend is already apparent from 1975 to the present. The past two decades have seen a sustained price reduction of 7.5\%/yr during which the average worldwide production of modules increased by $18 \% / y r$ [12]. In order to take advantages of economy of scale and to directly compete with fossil fuel as an energy source, it is generally agreed that $100 \mathrm{MWp} \mathrm{PV}$ plants must be constructed [29,35,36]. For PV modules produced at a $100 \mathrm{MWp}$ plant once financing, capital equipment costs, direct and indirect manufacturing costs, installation, power conditioning, operation and maintenance costs, and tax benefits are all taken into account, the installed PV price is likely to fall under $\$ 3.00 / \mathrm{Wp}(\mathrm{AC})$ [36]. This price makes solar cells economically attractive to a substantial portion of the United States' domestic energy market $\sim 8,000 \mathrm{MWp}$ [36]. The enormous market generated from the relatively small initial investment of $\$ 140$ million for a $100 \mathrm{MWp} / \mathrm{yr}$ plant has obvious implications for energy policy. A 100 $\mathrm{MWp} / \mathrm{yr}$ power plant is within reach of our current technology and is expected in the near future because once a single $100 \mathrm{MWp} / \mathrm{yr}$ power plant is constructed the market will demand 80 others identical to it. As multiple $100 \mathrm{MWp} / \mathrm{yr}$ plants are constructed the price of solar cells will continue to drop, opening the market to solar power generation even further.

The higher cost of power outside of the United States makes photovoltaic electrical production even more attractive, so large scale mass production of solar cells will be seen first outside of the U.S. N. Mori, the executive managing director of the Photovoltaic Power Generation Technology Research Association, predicts that Japan will begin producing 100 MWp/yr factories between 2003 and 2004 [19]. Thus, the world PV market is finally at the point where it has begun making the transition from the highly subsidized, grid connected market to the fully economic market. 
This is a final draft pre-print that was published in: Joshua Pearce, "Photovoltaics - A Path to Sustainable Futures", Futures 34(7), 663-674, 2002. Available: doi:10.1016/S0016-3287(02)00008-3

This transition will not disrupt the global economy or catalyze job loss. Opposing popular belief, use of photovoltaic technology actually leads to more jobs than it eliminates. Although, PV once installed is virtually maintenance free and thus devoid of employment for energy production, its fabrication and installation is extremely labor intensive. Thus, investment in solar energy produces substantially higher levels of employment than equivalent levels of investments in conventional energy supplies. A 1997 Pembina Institute report found that for every million dollars invested, an average of 12.2 jobs are created in the renewable energy sector (with PV being the most labor intensive resulting in the creation of 17 jobs). On the other hand, for every million dollars invested in conventional energy, an average of only 7.3 jobs are created [24]. It is predicted that by 2010 , approximately 70,000 new jobs could be created as a result of the increased demand for photovoltaic, solar hot water, and related solar energy systems through the installation of one million solar energy systems [37] representing only $3 \%$ of total U.S. energy production. The solar employment/energy ratio compares favorably to the relatively sparse job prospects of the coal industry that only employees $\sim 80,000$ to produce about $\sim 1 / 3$ of the energy in the U.S.

\section{Environmental Impacts and Sustainability}

Photovoltaics are truly a sustainable and environmentally friendly method of producing energy. PV produces no atmospheric emissions or radioactive waste during use. Therefore, when it replaces fossil fuel energy production it curtails air pollution, which produces acid rain, soil damage, and human respiratory ailments. PV electrical production also discharges no greenhouse gases, such as $\mathrm{CO}_{2}$, so it will help offset emissions that contribute to global warming.

Contrary to popular perceptions (even espoused by some misinformed environmentalists) solar photovoltaic modules are net energy producers. The myth that photovoltaics demand more energy to fabricate that they produce over their lifetime was refuted as early as 1978 [38]. That study was a limited life cycle analysis (LCA), which only considered the energy to fabricate the PV modules themselves. More detailed studies looked at different geographical locations and found the energy payback period ranged from 7.4 years (Detroit with frame) to 1.2 years (Phoenix without frame) [39]. Further studies compared PV made either from different materials or with different processes and found that crystalline silicon (c-Si) solar cells would pay for themselves in terms of energy in 11.8 to3.3 years, polycrystalline silicon (p-Si) solar cells in 2.4 to 1.5 years, and amorphous silicon (a-Si) solar cells in 2.1 to 1.1 years for a range of theoretical production facility outputs [40]. These analyses were made even more complete by Frankel et al. when they reported a complete LCA for both a power plant and several built in PV installations (1998). They included the balance of systems (BOS), materials, and module energy consumptions for grid connected homes. Using the average Italian solar flux of $1700 \mathrm{~kW}-\mathrm{hrs} / \mathrm{m}^{2}$ they found the energy payback times to range from 3 years (PV plant) to 1.5 years (PV integrated roof home) [41]. Next, Alsema finished a meta-analysis of the literature and found the energy payback periods to range from 4 to 2.6 years depending on the application and type of solar cell materials used [42]. With respect to the near-future poly-Silicon (poly-Si) and a-Si PV modules, the energy pay back time was estimated at approximately 2 years or less. In the case of a $10 \mathrm{MWp} / \mathrm{year}$ annual module production scale a-Si and poly-Si was less than that of $\mathrm{c}-\mathrm{Si}$ even if the energy content of the off grade $\mathrm{Si}$ is ignored [43] (note: presently BP-Solar is up to $8 \mathrm{MWp} / \mathrm{yr}$ in their amorphous silicon solar cell plant [44]). It is noteworthy that a-Si PV modules are able to 
This is a final draft pre-print that was published in: Joshua Pearce, "Photovoltaics - A Path to Sustainable Futures", Futures 34(7), 663-674, 2002. Available: doi:10.1016/S0016-3287(02)00008-3

recover the energy input in only a single year when the production scale reaches $100 \mathrm{MWp} / \mathrm{year}$ [43] (probably in 3-5 years [19]).

The apparent discrepancies caused by the energy payback periods would be expected of complete LCA studies. An LCA can never produce one simple result. The results are ranges of figures showing quantities of energy or materials used and waste generated. Any comparison between solar cells or the processes which produce them must clearly state both the stages the particular study evaluates and the assumptions made for which values could not be found. Ideally a complete life cycle analysis of a PV installation would include: material production energy, manufacturing energy of both the balance of system and the modules, energy use requirements, energy generation, end of use (disposal) energy, and the distribution/transportation energies in between each stage. Each stage of the life-cycle can then be organized into a product, process, and distribution component [45]. The product component of a PV system consists of materials incorporated into the PV module (such as stainless steel and ethylene-vinyl acetate (EVA) in the case of United Solar a-Si PV panels [39] or glass and EVA for BP-Solar a-Si panels in addition to the frame and semiconductor materials). These materials must be followed from the raw material acquisition through to the end-of-life management. The process component includes all fabrication and assembly steps and manufacturing facilities and equipment (this is generally the most straight forward stage to quantify because actual readings can be made during fabrication and the exact inputs and outputs can be determined for any given plant). Finally, the distribution component includes any packaging and transportation necessary to transfer the product materials between stages in the life-cycle. This is where a life-cycle analysis is most qualitative because it depends on variables such as distance to user, mode of transport (usually there would be several), where the panels are located geographically, type of disposal (mechanical separation of glass and roof construction materials from cells and plastic [46], primary recycling of frame or secondary, recycling of glass or dumping, and disposal of remaining materials in a high-active chemical landfill or possible reclamation of electronic materials) and users distance from disposal facility $20+$ years in the future, etc. In addition energy pay-back studies generally only analyze the panels themselves but also should evaluate the balance of system (BOS) energy costs: mounting, storage (such as batteries), tie-lines, inverters, charge controllers, etc. Kato et al. calculated the BOS and installation to be about $13 \%$ of the whole including an integrated frame, electric components, inverter, and installation [47] for a grid tied system. This value can be used to obtain realistic values of energy payback for complete PV systems from only module values. This is also only a qualitative estimate for a typical PV system- each installation would be slightly different.

No life cycle analysis study has been undertaken to look at all the variables in energy payback for a generic photovoltaic system simply because they are different depending on each application. The bottom line, however, is that PV produce far more energy than they use in their manufacture. The energy pay-back time for a typical $5 \mathrm{kWp}$ residential PV system (enough to power a large sized home) is conservatively less than five years which is much shorter than the expected lifetime, usually given as 20 years (but it should be noted that there is no physical reason that a solid state device such as a PV panel should ever fail from use - so the effective lifetime should be considered much longer than 20 years). Thus, because a PV panel produces far more energy over its lifetime than needed to produce it, PV represents a sustainable energy technology. 
This is a final draft pre-print that was published in: Joshua Pearce, "Photovoltaics - A Path to Sustainable Futures", Futures 34(7), 663-674, 2002. Available: doi:10.1016/S0016-3287(02)00008-3

The positive environmental impacts of PV are clearly illustrated with the same $5 \mathrm{kWp}$ photovoltaic system that could be placed on the roof of any typical home. Over a single year, this solar energy array would prevent: 3.3 tons of coal from being burned, 8.5 tons of $\mathrm{CO}_{2}$ from enhancing the greenhouse effect, $\sim 50$ pounds each of $\mathrm{NO}_{x}$ and $\mathrm{SO}_{2}$ from polluting the atmosphere and causing acid rain, 2.5 pounds of particulates from causing a health hazard, 571 pounds of ash from being disposed of in landfills, and conserve over 5,000 gallons of water ${ }^{5}$. A typical solar cell has a 20-25 year official lifetime ${ }^{6}$ and thus the propensity for incredible pollution mitigation.

Photovoltaic technology is obviously an enormous environmental benefit. It represents a sustainable solution to our current energy requirements because the active material making up the majority of PV cells is silicon, which is readily available in sand. Also, the abundant energy a single PV generates over its lifetime could be used to produce more PV identical to it. Thus PV is a true breeding technology - it can reproduce itself sustainably over time while providing for society's energy needs.

\section{Social Consequences of Converting to Solar Power}

In stark contrast to the energy sources of the past, active solar technology has a plethora of positive social consequences and could even assist in increasing social equity. Photovoltaic energy production will benefit global society by creating jobs, distributing energy supplies, and preventing pollution that results in health, and environmental degradation.

Photovoltaic energy production can assist individual self-reliance. By the very nature of photovoltaic technology it is a distributed energy system. Thus, the energy can be generated where it is consumed, and thus does not have to rely on a grid (known to have frequent power failures). The consumer also avoids being coerced into purchasing power from a supplier. This ability to produce one's own power allows for greater personal freedom while preserving all the amenities of modern life.

Being that PV is truly a universal power source (almost everyone has access to the sun) this technology has the propensity to be an equalizing factor in wealth disparity between both rich and poor countries but also rich and poor individuals. As compared to developed countries, developing countries possess a strategic advantage for adopting PV because of their much lower technological inertia. They posses a much lower level of commitment to fossil fuel technologies in terms of infrastructures, capital vintages, employment skills, management organization, and political institutions. The developing countries could effectively 'leap frog' antiquated energy technologies rather than follow exactly in the historical path of developed nations. However, it should be noted, that any form of electrical energy is prohibitively expensive for the average citizens of developing nations. In developed nations, the current high price of home-based PV systems is also prohibitive to most homeowners. Thus, only upper or upper-middle class individuals have purchased PV systems. However, as prices continue to plummet with rising production volume the cost of a PV system is entering the price range of middle and lower class citizens. Already PV has found a niche market in mobile campers. This vanguard of PV owners will help acclimate the general public to the use of PV. This growing familiarity and the

\footnotetext{
${ }^{5}$ Calculations are based on data from a 500MW Coal fired power plant and assuming 1600 peak hrs/yr. [48]

${ }^{6}$ Theoretically solid-state devices like PV cells and solid-state lasers should continue to function indefinitely. In fact, the first silicon solar cells are still in operation today.
} 
independence from paying electrical utility bills every month alone is a strong incentive for individuals to convert their homes to solar power electrical generations stations.

The benefit of PV power generation to the health of current population but more importantly for future generations is clear. Due to the offset of air pollution $\left(\mathrm{NO}_{\mathrm{X}}, \mathrm{SO}_{2}\right.$, and particulate emissions) from coal produced electricity there are immediate health benefits such as reduction in premature mortality from respiratory disease and chronic bronchitis. Reduction in air pollutants also helps less serious maladies like reduction of asthma symptoms, acute lower respiratory symptoms, and restricted activity days (days in the hospital) [49].

\section{Conclusion}

Solar photovoltaic technology provides a technologically feasible solution to societies current health and environmental dilemmas posed by the reliance on fossil fuel based power generation. Solar energy is already economically viable in many applications, and will continue to expand as production continues to increase in scale. Economics of scale will decrease the cost of solar energy while simultaneously facilitating net job creation. PV will not only enhance social equity by creating jobs, but as a distributed energy source it will enable individuals to be more self-reliant without forsaking modern conveniences and technology. In addition, photovoltaic energy production represents an environmentally beneficial and sustainable method of maintaining an energy intensive standard of living, which will enable development without compromising those who will live in the future to do the same.

\section{Acknowledgements}

The author would like to acknowledge helpful discussions with C. Wronski and R. Koval, of the Center for Thin Film Devices, A. Lau of the College of Engineering, and S. Eser of The Energy \& Geo-Environmental Engineering Department at The Pennsylvania State University. 
This is a final draft pre-print that was published in: Joshua Pearce, "Photovoltaics - A Path to Sustainable Futures", Futures 34(7), 663-674, 2002. Available: doi:10.1016/S0016-3287(02)00008-3

\section{References}

1. Keeling C D and Tans P. In: Houghton J, editor, Global Warming: the complete briefing. Cambridge, UK: Cambridge University Press, 1997.

2. Meadows D H, Meadows D I, Randers J, and Behrens III WW. The limits to growth. New York: Universe Books, 1972.

3. Peet J. Energy and the ecological economics of sustainability, Washington, D.C: Island Press, 1992.

4. Minger T. Greenhouse glasnost: the crisis of global warming. New York: Institute of Resource Management, 1990.

5. Epstein P R, Haines A, McMichael A J. Canadian Medical Assn Journal 2000, 163(6): 729-734.

6. World's Commission on Environment and Development, Our common future (The Bruntland Report). New York: Oxford University Press, 1987.

7. French H. Vanishing borders: protecting the planet in the age of globalization. New York: W.W. Norton \& Company Inc., 2000.

8. Flavin C. Building a bridge to sustainable energy, In Brown L. editor, State of the World 1992, New York: Worldwatch Institute and Norton, 1992.

9. Harper P. The end in sight? Some speculations on environmental trends in the twentyfirst century, Futures 2000; 32:361-384.

10. Turner J A. A realizable renewable energy future, Science 1999; 285(5427): 687-689.

11. Rose A. Global view of solar energy in rational units, Phys. Stat. Sol (A) 1979, 56: 11-26.

12. Shah A, Torres P, Tscharner R, Wyrsch N, and Keppner H. Photovoltaic technology: the case for thin-film solar cells, Science 1999; 285(5427): 692- 698.

13. Houghton J.T. et al., Climate Change 1992: The Supplementary Report to the IPCC Scientific Assessment. New York: Cambridge University Press, 1992.

14. World Resources Institute, World Resources 1994-95. New York: Oxford University Press, 1994.

15. The Intergovernmental Panel on Climate Change (IPCC). Climate change 1995:the science of climate change, summary for policy makers and technical summary and IPCC Second Assessment Report: Climate Change. New York: United Nations Environment Program and World Meteorological Organization, 1995.

16. IPCC, Summary for Policymakers, Climate Change 2001: Impacts, Adaptation, and Vulnerability, http://www.usg.crp.gov/ipcc/wg2spm.pdf, visited April 24, 2001.

17. English Conference of the Parties Third session Kyoto, Kyoto Protocol to the United Nations Framework Convention on Climate Change, 1-10 December 1997, http://www.cnn.com/SPECIALS/1997/global.warming/stories/treaty/ visited April 27, 2001.

18. Dunn, S. Chapter 5 Decarbonizing the Energy Economy in State of the World 2001, World Watch Institute, 2001, New York: W.W. Norton \& Company, 2000.

19. Mori N. Current status and future prospects of photovoltaic technology development program in Japan, Proceedings of the $28^{\text {th }}$ IEEE Photovoltaic Specialists Conference $2000 ; 1730-1733$. 
This is a final draft pre-print that was published in: Joshua Pearce, "Photovoltaics - A Path to Sustainable Futures", Futures 34(7), 663-674, 2002. Available: doi:10.1016/S0016-3287(02)00008-3

20. Maycock P. D. The world PV market 2000 - shifting from subsidy to 'fully economic'?, Renewable Energy World Review Issue 2000, 3(4) 59-74.

21. d'Estaintot T. European commission-supported R\&D activities in the field of photovoltaics, Proceedings of the $28^{\text {th }}$ IEEE Photovoltaic Specialists Conference 2000; 1734-1735.

22. Rannels J.E. Outlook for the US PV research program and its implications for terrestrial systems and applications, Proceedings of the $28^{\text {th }}$ IEEE Photovoltaic Specialists Conference 2000; 1736-1739.

23. U.S. Department of Energy. The Million Solar Roofs Initiative. http://www.eren.doe.gov/millionroofs/background.html visited April 25, 2001.

24. Pembina Institute, Comparative Analysis of Employment from Air Emission Reduction Measures. (for Environment Canada). 1997, also LOW IMPACT RENEWABLE ENERGY: Options for a Clean Environment and Healthy Canadian Economy, September 1999.

25. Carlson D E. Fossil fuels, the greenhouse effect and photovoltaics. IEEE Photovoltaic Specialists Conference 1988; 1-7.

26. Stoett P J. Global environmental security, energy resources and planning. Futures 1994; 26(7): 741-758.

27. The New Energy and Industrial Technology Development Organization. Solar \& wind energy utilization technology, http://www.nedo.go.jp/taiyo/eng/intro/index.htm, visited April 24, 2001.

28. Knapp K E, Jester T L, and Mihalik G B. Energy balances for photovoltaic modules: status and prospects, Proceedings of the $28^{\text {th }}$ IEEE Photovoltaic Specialists Conference 2000; 1450-1455.

29. Schramm G and Kern E. Accelerating photovoltaic production through grid connected applications in developing countries, Proceedings of the $28^{\text {th }}$ IEEE Photovoltaic Specialists Conference 2000; 36-39.

30. National Renewable Energy Laboratory, Average Daily Solar Radiation, 1961-1990, www.azsolarcenter.com/arizona/solmap.html visited January 10, 2001.

31. Trends in Renewable Energy, Issue 144, week of Aug. 21 to Aug 25, 2000. http://www.solaraccess.com/sanews/trends/default.asp visited April 27, 2001.

32. Energetics Inc., U.S. Photovoltaics Industry PV Technology Roadmap Workshop, September 30, 1999. http://www.nrel.gov/ncpv/pdfs/30150.pdf visited April 27, 2001.

33. Department of Energy, Annual Energy Outlook 1999, DOE/EIA-0383(99), Energy Information Administration, 1998.

34. Perez R. Hidden energy costs, Home Power Magazine 1990; 16(April/May): 21. Initial data from 1989 ASES Roundtable: Societal Costs of Energy.

35. DeMeo E. Network PV: Cost Reduction Prospects, Renewable Energy Consulting Services, Inc. for the International Finance Corporation, March 30, 1999.

36. Payne A M, Duke R D, and Williams R H. The Impact of Net Metering on the Residential Rooftop PV Market, Proceedings of the $28^{\text {th }}$ IEEE Photovoltaic Specialists Conference 2000; 1391-1394.

37. The U.S. Department of Energy, The 2000-2001 Million Solar Roofs Action Plan, http://www.eren.doe.gov/millionroofs/pdfs/action plan.pdf visited April 27, 2001. 
This is a final draft pre-print that was published in: Joshua Pearce, "Photovoltaics - A Path to Sustainable Futures", Futures 34(7), 663-674, 2002. Available: doi:10.1016/S0016-3287(02)00008-3

38. Wihl, M. and Scheinine, A., Analysis and simulation of the energy source of the future: the solar breeder, IEEE PVSEC Proceedings 1978; 908-910.

39. Keoleian, G.A. and Lewis, G.M., Applications of life-cycle energy analysis to photovoltaic module design, Progress in Photovoltaics: Research and Applications 1997; 5:287-300.

40. K. Kato, A. Murata, and K Sakuta, An evaluation on the life cycle of photovoltaic energy system considering production energy of off-grade silicon, Sol. Energy Mat. and Sol. Cells 1997; 47:95-100.

41. P. Frankl, A. Masini, M. Gamberale, and D. Toccaceli, Simplified life-cycle analysis of PV systems in buildings: Present situation and future trends, Progress in Photovoltaics: Research and Applications 1998; 6:137-146.

42. E. Alsema, Energy pay-back time and $\mathrm{CO}_{2}$ emissions of PV systems, Progress in Photovoltaics: Research and Applications 2000; 8:17-25.

43. Kato, K., Maruta, A., and Sakuta, K., Energy pay-back time and life-cycle CO2 emission of residential PV power system with silicon PV module, Progress in Photovoltaics: Research and Applications 1998; 6:105-115.

44. Carlson D., Chief Scientist and Director Advanced Material and Device Research BP Solar, personal communication April 19, 2001.

45. Keoleian, G.A., Koch, J. and Menerey, D., Life-Cycle design framework and demonstration project: Profiles of AT\&T and Allied Signal. US Environmental Protection Agency. Office of Research and Development, Washington DC, EPA/600/R95/107, 1995.

46. Dones, R., Gatner, U, Hirschberg, S., Doka, G., and Knoepfel, I., Environmental Inventories for Future Electricity Supply Systems for Switzerland, PSI Rep. No. 96-07, Wurenlingen \& Villigen, Switzerland, 1996.

47. Dones, R. and Frischknecht, R., "Life-cycle assessment of photovoltaic systems: results of Swiss Studies on Energy chains", Progress in Photovoltaics: Research and Applications 1998; 6:117-125.

48. Union of Concerned Scientists briefing: How does Coal work? http://www.ucsusa.org/energy/brief.coal.html visited April 27, 2001.

49. United States Environmental Protection Agency. Office of Air and Radiation, Acid Rain Division, Human Health Benefits from Sulfate Reduction Under Title IV of the 1990 Clean Air Act Amendments, November 1995. http://www.epa.gov/acidrain/effects/healthx.html visited January 7, 2001. 
This is a final draft pre-print that was published in: Joshua Pearce, "Photovoltaics - A Path to Sustainable Futures", Futures 34(7), 663-674, 2002. Available: doi:10.1016/S0016-3287(02)00008-3

\section{Vitae}

Joshua Pearce is currently pursuing his Ph.D. in Materials Science and Engineering with a graduate minor in Science, Technology, and Society (STS) at the Pennsylvania State University. His research is divided into three complementary parts: the study of hydrogenated amorphous silicon materials, their corresponding solar cells, and the environmental and economic aspects of these photovoltaic technologies. 